\title{
Infections by Kudoa ciliatae (Myxozoa: Myxosporea) in Indo-Pacific whiting Sillago spp.
}

\author{
Sascha L. Hallett*, Peter J. O'Donoghue, Robert J. G. Lester \\ Department of Parasitology, The University of Queensland, Brisbane 4072, Queensland, Australia
}

\begin{abstract}
Infections by Kudoa ciliatae Lom, Rohde \& Dyková, 1992 were detected in 141 (32\%) of 444 Indo-Pacific whiting Sillago spp. caught in Moreton Bay, Australia. The parasite was detected in the type host, $S$. ciliata (in $14 \%$ of 73 fish), and from 2 new hosts, S. maculata $(46 \%$ of 264 ) and $S$. analis $(9 \%$ of 107$)$. Prevalence of infection in S. maculata was greatest in autumn $(100 \%)$ and lowest in spring $(10 \%)$, the seasonal differences being positively correlated to host size (more prevalent in larger fish caught in autumn). Intensity of infection ranged from 1 to 45 cysts per fish (mean 7.6) and the cysts measured up to $2.5 \mathrm{~mm}$ in length. Most cysts were located on the serosal surface of the intestinal tract extending into the circular smooth muscle layer. The majority were found in the distal third of the intestine, often in groups of 2 to 5 cysts. Parasites were also found for the first time in the pyloric caeca, intestinal mesentery and liver. Calcified cysts were occasionally detected in S. ciliata and $S$. analis.
\end{abstract}

KEY WORDS: Myxozoa $\cdot$ Kudoa ciliatae $\cdot$ Whiting $\cdot$ Sillago spp. Prevalence Morphology

\section{INTRODUCTION}

Protozoan parasites belonging to the phylum Myxozoa are common in marine and freshwater fish throughout the world. Numerous studies have described parasite developmental stages (e.g. Lester 1982, Hedrick et al. 1991, Lom et al. 1992, Dyková et al. 1994) and the pathology of infections (e.g. Whitaker \& Kabata 1987 , Langdon 1991, Alvarez-Pellitero \& Sitjà-Bobadilla 1993, Roubal 1994), but little information is available on the distribution and abundance of the parasites, particularly in Australian fish (see Lom et al. 1992, Su \& White 1994). Two orders of Myxosporea are recognised on the basis of spore morphology: the Bivalvulida (spores with 2 valves) and the Multivalvulida (spores with more than 2 valves). Species belonging to the latter group occur predominantly as histozoic parasites in the skeletal muscles of marine fish (see Lom \& Dyková 1992). The few remaining species have been described from tissues that include the the gills, brain, gall blad-

·E-mail: s305713@student.uq.edu.au der and pericardial cavity (Lom \& Dyková 1992). One species, Kudoa ciliatae Lom, Rohde \& Dyková, 1992, has been reported to form cysts in the smooth muscles of the intestines of sand whiting Sillago ciliata Cuvier. Preliminary studies found similar cysts in the intestines of winter whiting Sillago maculata Quoy \& Gaimard, collected in south-east Queensland (Heath 1980). The present investigation was performed to determine the identity, prevalence and intensity of infections in Indo-Pacific whiting Sillago spp. from Moreton Bay, Queensland, Australia.

\section{MATERIALS AND METHODS}

Whiting were caught by beach seine at 4 sites in Moreton Bay (Scott Point, Woody Point, Sandgate and Cabbage Tree Creek). A total of 444 whiting belonging to 3 species, 264 Sillago maculata, 73 S. ciliata and $107 \mathrm{~S}$. analis Whitley (golden-lined whiting), were collected over a 14 mo period (March 1994 to April 1995). The fish were transported live to the laboratory, anaesthetised in $0.01 \%$ methanesul- 
fonate salt (Sigma) and pithed. Their alimentary canals were removed and examined under a dissection microscope for myxosporean cysts. The sites of infection were recorded and cyst sizes scored on a scale of 1 to 5 (indicating length $<500 \mu \mathrm{m}, \approx 500 \mu \mathrm{m}$, 500-1000 $\mathrm{m}, 1-2 \mathrm{~mm}$ or $>2 \mathrm{~mm}$ respectively). Infected tissues were fixed in $10 \%$ buffered formalin and processed into paraffin wax using standard histological procedures. Sections were cut at 5 to $8 \mu \mathrm{m}$, stained with Mayer's haematoxylin and eosin or Giemsa and examined at 40 to $1000 \times$ magnification using a compound light microscope. Squash preparations of fresh cysts were also prepared and mature spores were measured using a calibrated eyepiece graticule. Numeric data were examined for significant relationships $(\mathrm{p}>0.05)$ by $t$-tests, analyses of variance and regression analyses using the Statistix ${ }^{(B)}$ software package.

\section{RESULTS}

Description of parasite

In wet preparations of cysts, the mature spores were observed to be pyramidal, containing 4 valves and 4 phase-bright pyriform polar capsules arranged in a characteristic cross formation at the apex (Fig. 1). The dimensions of the spores ranged from 5.1 to $7.1 \mu \mathrm{m}$ in length, 7.1 to $8.7 \mu \mathrm{m}$ in width and 5.1 to $7.1 \mu \mathrm{m}$ in height (Table 1). No significant differences in spore dimensions were observed within or between the different host species. The spores were identified as Kudoa ciliatae Lom, Rohde \& Dyková, 1992.

Macroscopic cysts appeared as white elliptical bodies embedded in the host tissues, usually with their long axes perpendicular to the length of the intestines (Fig. 2). Cysts were frequently detected in small clus-
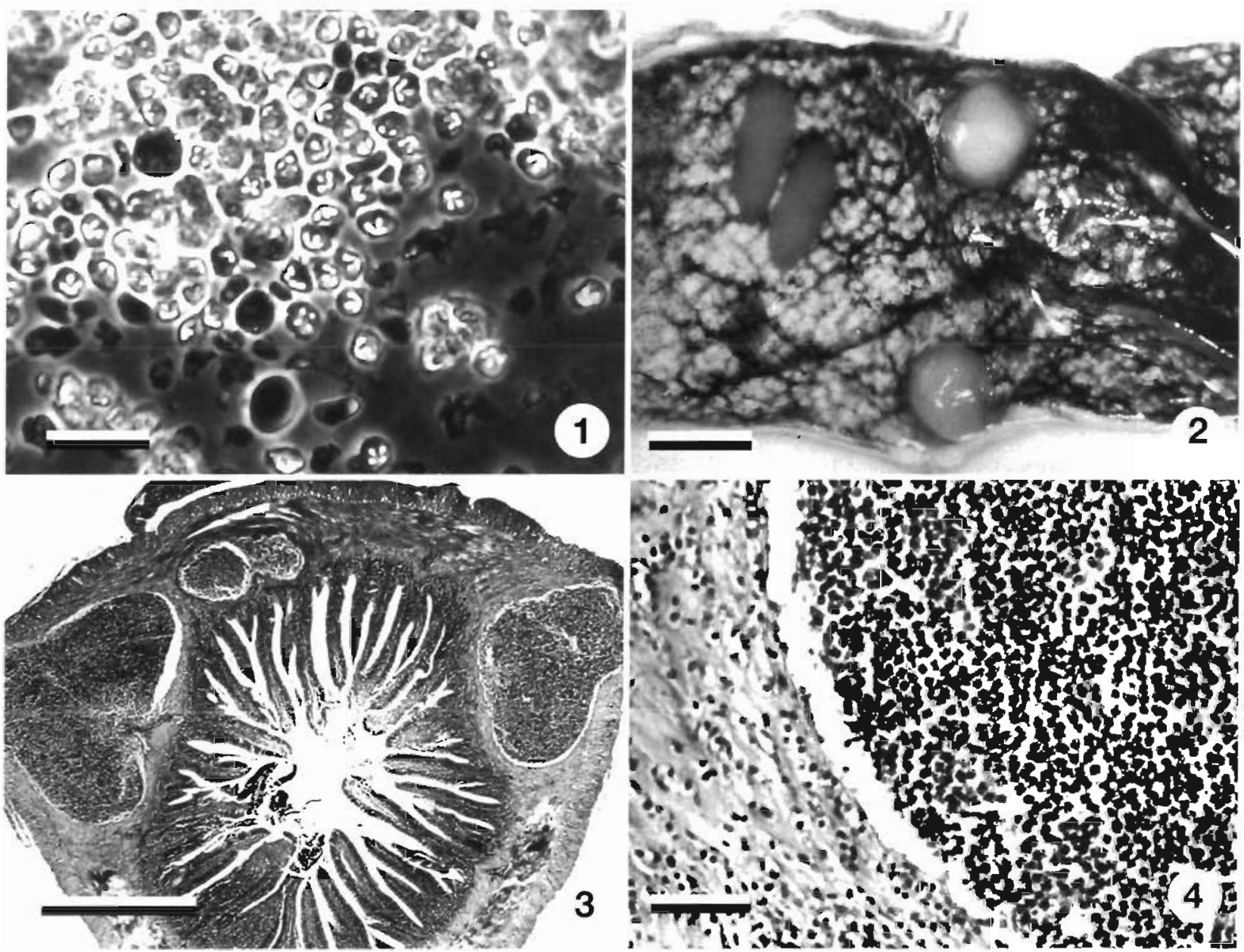

Figs. 1 to 4. Light micrographs of Kudoa ciliatae from tissues of whiting Sillago spp. Fig. 1. Mature spores, some exhibiting 4 distinct polar capsules, recovered from cyst. Scale bar $=20 \mu \mathrm{m}$. Fig. 2. Macroscopic cysts visible through serosal surface of intestine. Scale bar $=1 \mathrm{~mm}$. Fig. 3. Section through cysts located in distended inner circular smooth muscle layer of distal intestinal wall. Giemsa. Scale bar $=1 \mathrm{~mm}$. Fig. 4. Section through periphery of cyst showing thin cyst wall surrounding numerous spores. 
Table 1. Morphometrics of mature spores of Kudoa ciliatae from Sillago maculata. $\bar{x}$ : mean; SD: standard deviation; $\mathrm{CV}$ : coefficient of variation; min: minimum; max: maximum; n: number of observations

\begin{tabular}{|lcccccc|}
\hline Spore dimensions & $\bar{x}$ & SD & CV & Min & Max & $\mathrm{n}$ \\
\hline Length, $L(\mu \mathrm{m})$ & 6.0 & 0.42 & 7.06 & 5.1 & 7.1 & 40 \\
Width, $W(\mu \mathrm{m})$ & 7.7 & 0.53 & 6.82 & 7.1 & 8.7 & 40 \\
Height, $H(\mu \mathrm{m})$ & 5.9 & 0.61 & 10.20 & 5.1 & 7.1 & 40 \\
\hline
\end{tabular}

ters and $83 \%$ were found in groups of 2 to 5 cysts of similar size. Most cysts were soft and pliable when probed although hard yellow cysts were occasionally detected in Sillago ciliata and $S$. analis. The majority of cysts were detected on the serosal surface of the intestines and pyloric caeca and some were occasionally observed in the intestinal mesentery. The only exception was the detection of several cysts attached to the liver of one $S$. maculata. Histological examination revealed the cysts in the intestine and pyloric caeca to be located in the inner circular muscle layer of the smooth muscle (Fig. 3). Cysts were located deeper in the muscle layer of $S$. ciliata than of $S$. maculata or $S$. analis. Irrespective of their size, the cysts did not penetrate into the submucosa or mucosa and the gut lumen was never obstructed or occluded. Instead, the cysts projected outwards distending the outer longitudinal muscle layer and serosal membranes into the abdominal cavity. Cysts located in the intestinal mesentery or attached to the liver appeared to be surrounded by a thin layer of connective tissue. Because infections were rarely encountered at these sites, they were considered to represent atypical or ectopic sites of infection. None of the cysts were associated with any conspicuous inflammatory reactions. The cysts were bounded by thin membranous cyst walls which were frequently disrupted in histological sections by shrinkage artefacts (Fig. 4). The cysts were packed with numerous basophilic spores measuring approximately $6 \mu \mathrm{m}$ in diameter.

\section{Infection parameters}

Kudoa ciliatae cysts were detected in the alimentary tracts of 121 (46\%) of 264 Sillago maculata, $10(14 \%)$ of 73 S. ciliata and $10(9 \%)$ of 107 S. analis (Table 2). The prevalence of infection was significantly greater in $S$. maculata than in the other 2 species. The intensity of infection ranged from 1 to 45 cysts per fish (Table 2) and was significantly greater in $S$. ciliata (mean of 12.1 cysts per fish) than in $S$. maculata ( 7.6 cysts) and $S$. analis (2.2 cysts). Statistical analyses revealed significant spatial and temporal differences in the prevalence and intensity of infections in $S$. maculata (the
Table 2. Prevalence and intensity of infections by Kudoa ciliatae in 3 Sillago spp. from Moreton Bay, Australia

\begin{tabular}{|lrrrrr|}
\hline $\begin{array}{l}\text { Host } \\
\text { species }\end{array}$ & $\begin{array}{l}\text { No. ex- } \\
\text { amined }\end{array}$ & $\begin{array}{r}\text { No.in- } \\
\text { fected }\end{array}$ & $\begin{array}{c}\% \text { pre- } \\
\text { valence }\end{array}$ & $\begin{array}{c}\text { No. } \\
\text { cysts/fish }\end{array}$ & $\begin{array}{c}\text { Mean } \\
\text { intensity }\end{array}$ \\
\hline S. maculata & 264 & 121 & $46 \%$ & $0-41$ & 7.6 \\
S. analis & 107 & 10 & $9 \%$ & $0-5$ & 2.2 \\
S. ciliata & 73 & 10 & $14 \%$ & $0-45$ & 12.1 \\
Total & 444 & 141 & $32 \%$ & $0-45$ & 7.5 \\
\hline
\end{tabular}

small number of infections detected in $S$. ciliata and $S$. analis prohibited meaningful analyses). Infections in S. maculata were more prevalent at Scott Point (49\%) than at other sampling sites $(35 \%)$ and the intensity of infection was greater at Scott Point ( 8.5 cysts per fish) than elsewhere ( 4 cysts per fish) (Table 3 ). All fish examined were juveniles or immature adults so the sex distribution of infections could not be determined. A positive correlation was found between the prevalence of infections and fish length (Fig. 5). Infections were most prevalent in larger fish $(>8 \mathrm{~cm})$ which were caught in autumn and least prevalent in smaller fish $(<8 \mathrm{~cm})$ caught in spring. The overall infection prevalence was thus greatest in autumn $(100 \%)$, decreased over winter, becoming lowest in spring (10\%), then increasing during summer (Fig. 6). Minor seasonal fluctuations were observed in the intensity of infections with heavier infections occurring in autumn and lighter infections in spring and winter (Fig. 6).

Table 3. Prevalence and intensity of Kudoa ciliatae infections in Sillago maculata from 2 different locations within Moreton Bay, Australia

\begin{tabular}{|lrrrrc|}
\hline $\begin{array}{l}\text { Host } \\
\text { species }\end{array}$ & $\begin{array}{l}\text { No. ex- } \\
\text { amined }\end{array}$ & $\begin{array}{l}\text { No.in- } \\
\text { fected }\end{array}$ & $\begin{array}{c}\% \text { pre- } \\
\text { valence }\end{array}$ & $\begin{array}{c}\text { No. } \\
\text { cysts/fish }\end{array}$ & $\begin{array}{c}\text { Mean } \\
\text { intensity }\end{array}$ \\
\hline Scott Point & 198 & 98 & $49 \%$ & $0-41$ & 8.5 \\
Other sites & 66 & 23 & $35 \%$ & $0-9$ & 4.0 \\
Total & 264 & 121 & $46 \%$ & $0-41$ & 7.6 \\
\hline
\end{tabular}

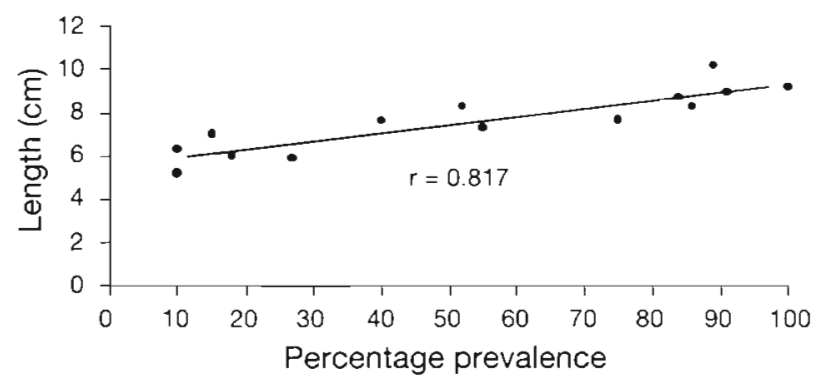

Fig. 5. Correlation between length of Sillago maculata and prevalence of infection by Kudoa ciliatae 


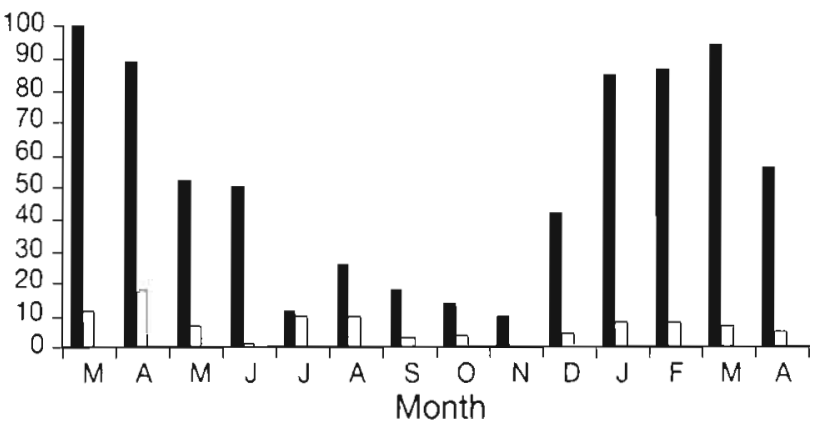

Fig. 6. Seasonal variation in percentage prevalence (black bars) and mean intensity (white bars) of infections by Kudoa ciliatae in Sillago maculata

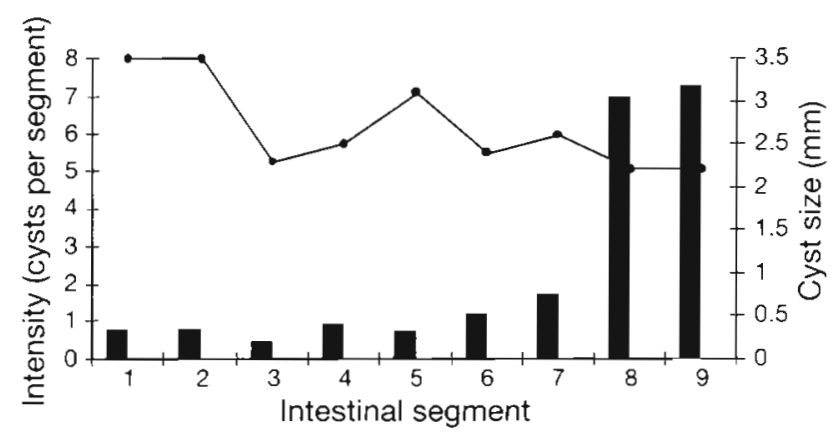

Fig. 7. Mean intensity (bars) and sizes (line) of Kudoa ciliatae cysts in proximal $(1-3)$, middle $(4-6)$ and distal $(7-9)$ segments of intestines of Sillago maculata

Infections were detected within similar tissues and organs in the 3 host species but cysts were consistently larger in Sillago maculata (ranging from 0.1 to $2.5 \mathrm{~mm}$ in length) than in $S$. ciliata $(0.1$ to $0.5 \mathrm{~mm})$ and $S$. analis $(0.1$ to $0.2 \mathrm{~mm})$. The spatial distribution of cysts along the intestines was determined for $34 S$. maculata by recording the numbers of cysts present in each of the 3 intestinal loops (each loop arbitrarily divided into 3 segments of equal length). Cysts were detected more frequently in the distal third of the intestines $(67 \%)$ than in the proximal or middle thirds $113 \%$ and $20 \%$ respectively). The intensity of infection was greatest in the 2 distal segments whereas the cysts were generally larger in the 2 proximal segments (Fig. 7).

\section{DISCUSSION}

The morphological characteristics of the myxosporean cysts and spores detected in Sillago ciliata, $S$. maculata and $S$. analis from Moreton Bay were consistent with those previously described for Kudoa ciliatae originally described from $S$. ciliata caught off the coast of New South Wales in Australia. However, the spores found in the 3 different Sillago spp. were slightly larger than those originally described from $S$. ciliata (mean dimensions of $6.0 \times 7.7 \times 5.9 \mu \mathrm{m}$ compared to $5.4 \times 6.6 \times 5.5 \mu \mathrm{m}$ ) but the size ranges of the spores exhibited considerable overlap. Some size variation may have been due to the use of different preparative or examination techniques, especially those involving fixation resulting in shrinkage, although many myxosporean species have been found to form spores varying greatly in size, e.g. $K$. clupeidae and K. paniformis (see Lom \& Dyková 1992). The largest cysts detected in $S$. ciliata in this study were twice the size of those recorded by Lom et al. (1992) and those found in $S$. maculata were up to 10 times larger. It is not known whether cysts grow at different rates in different host species or whether cyst size is related to host age or the longevity of infection. In this study, no correlation was found between cyst size and fish length, and older fish (presumably with longer standing infections) did not have larger cysts. The developmental cycle of $K$. ciliatae has yet to be determined and comparative studies are required to establish the kinetics and dynamics of infections in different host species.

Many of the infection parameters examined in this study (prevalence, intensity and cyst size) were found to vary according to geographic location, season of sample, host species, host size or site of infection. The prevalence of infection was greater in Sillago maculata than in $S$. ciliata or $S$. analis although all 3 species have a similar geographic distribution and are often observed in mixed schools (McKay 1985). All species are benthic feeders and dig for worms and small crustaceans (Maclean 1971, Burchmore et al. 1988, Brewer \& Warburton 1992). Because a number of freshwater myxosporean species have been found to have alternate life cycle stages in freshwater oligochaetes (reviewed by Kent et al, 1993), the different levels of Kudoa ciliatae infection in whiting may be related to their proximity to infected intermediate hosts. However, the complete life cycle of $K$. ciliatae, and that of any marine myxosporean species, has yet to be determined and it is not known whether alternate (actinosporean?) life cycle stages in marine worms are involved.

Considerable variation was observed in the prevalence and intensity of infections in fish from different geographic locations within Moreton Bay and infections were less prevalent in Sillago ciliata from Moreton Bay than in those from New South Wales, $14 \%$ compared to $44 \%$ (Lom et al. 1992). The samples from New South Wales were all collected during spring (the season in which we recorded lowest prevalence of infection) and the fish were larger than those examined in this study; 12 to $17 \mathrm{~cm}$ in length compared to 5 to $16 \mathrm{~cm}$ (J. Lom pers. comm.). 
Significant seasonal differences were found in the prevalence of infections in Sillago maculata, apparently following an annual cycle, being highest in autumn and lowest in spring, which did not correspond exactly to the thermal cycle but rather lagged some 2 to 3 mo. This lag period may represent the time required for cyst development following infection in warmer waters over summer. Development of myxosporeans in freshwater fish has been demonstrated to take between 3 and 4 mo (Ruidisch et al. 1991, Yokoyama et al. 1991, El-Matbouli et al. 1992, Kent et al. 1993, Yokoyama et al. 1993). Alternatively, the seasonal differences in infections may be related to seasonal changes in host populations. A positive correlation was indeed found between the prevalence of infections and fish length, infections being more prevalent in larger fish caught in autumn. S. maculata have been reported to spawn in spring (Roughley 1964) and summer (Burchmore et al. 1988) and to grow to $8 \mathrm{~cm}$ in $1 \mathrm{yr}$ (Weng 1983). Consequently, small juvenile fish $(<8 \mathrm{~cm})$ are abundant in shallow water populations over winter and spring while larger juveniles $(>8 \mathrm{~cm}$ ) predominate over summer and autumn. The seasonal differences observed in the prevalence of infections therefore appear to be related to the ages of the fish, infections being more prevalent in older fish. This may be due to their longer exposure to infections rather than to differences in their susceptibility. The extent of infections in adult fish remains to be determined as none were caught in this study. Fish approaching first maturity $(>19 \mathrm{~cm})$ have been found to migrate to deeper waters (Burchmore et al. 1988) and are not accessible by beach seine netting.

Lom \& Dyková (1992) observed that younger fish were generally more susceptible to myxosporean infections and that some infections accumulate with age. In the present study, heavier Kudoa ciliatae infections were detected in larger Sillago maculata. This suggests either that fish have acquired more parasites with age or that the parasites have proliferated with time within their hosts. The cysts detected within individual fish were not uniform in size, which suggests that multiple infections occurred or that parasite proliferation was not synchronous. Lom \& Dyková (1992) have postulated that heavy infections by histozoic myxosporean species result from extrasporogonic proliferation within host tissues. Infections presumably spread into neighbouring tissues, which could explain the focal aggregations of cysts and their increasing frequency and intensity further down the intestinal tract. However, it seems more likely that each cyst arises from one sporoplasm and that the clusters of cysts arise from the several sporoplasms released from a single spore.

The majority of Kudoa ciliatae cysts were detected in the circular smooth muscle layer of the intestines and pyloric caeca and the distribution of $K$. ciliatae cysts along the intestines was not uniform. Many other parasite species exhibit preferential or predilection sites of infection. For example, Oliva et al. (1992) found significantly greater numbers of $K$. sciaenae cysts in the anterior skeletal muscles of their hosts and considered this to be related to the differential distribution of muscle mass. Not surprisingly, most $K$. ciliatae cysts were detected in anatomical sites where the smooth muscle layers were thickest and also enlarged to form the ileorectal valve and anal sphincter (Fänge \& Grove 1979, Hibiya 1982).

Few host responses to infection were observed even though many cysts were macroscopic and disrupted tissue architecture. Hard yellow cysts found occasionally suggest that calcareous degeneration of some cysts did occur. Many multivalvulid myxosporean species have been associated with various pathological conditions, including muscle melanization, e.g. Kudoa paniformis in hake (Lom \& Dyková 1992), post-mortem myoliquefaction, e.g. K. thyrsites in mahi mahi (Langdon 1991) and Unicapsula seriolae in yellowtail kingfish (Lester 1982), and even mortalities, e.g. K. thyrsites in salmon (Harrel \& Scott 1985). In contrast, infections by $K$. ciliatae have not been associated with clinical disease in subadult Indo-Pacific whiting but further studies are required to determine whether infections affect larvae or early juvenile fish as well as to establish the mode of transmission between hosts

Acknowledgements. This study was supported in part by a scholarship from the Department of Parasitology at The University of Queensland to the first author. The authors thank Stephen Atkinson and Eric Boel for their assistance in the field collection of fish.

\section{LITERATURE CITED}

Alvarez-Pellitero P, Sitjà-Bobadilla A (1993) Pathology of Myxosporea in marine fish culture. Dis Aquat Org 17: $229-238$

Brewer DT, Warburton K (1992) Selection of prey from a seagrass/mangrove environment by golden lined whiting, Sillago analis (Whitley). J Fish Biol 40:257-271

Burchmore JJ, Pollard DA, Middleton MJ, Bell JD, Pease BC (1988) Biology of four species of whiting (Pisces: Sillaginidae) in Botany Bay, New South Wales. Aust J Mar Freshwat Res 39:709-727

Dyková I, Lom J, Overstreet RM (1994) Myxosporean parasites of the genus Kudoa Meglitsch, 1947 from some Gulf of Mexico fishes: description of two new species and notes on their ultrastructure. Eur J Protistol 30:316-323

El-Matbouli M, Fischer-Scherl T, Hoffmann RW (1992) Transmission of Hoferellus carassi Achmerov, 1960 to goldfish Carassius auratus via an aquatic oligochaete. Bull Eur Assoc Fish Pathol 12:54-56

Fänge R, Grove D (1979) Digestion. In: Hoar WS, Randall DJ, Brett JR (eds) Fish physiology. Academic Press, New York, p $162-260$ 
Harrel LW, Scott TM (1985) Kudoa thyrsitis (Gilchrist) (Myxosporea: Multivalvulida) in Atlantic salmon, Salmo salar L. J Fish Dis 8:329-332

Heath BM (1980) Phenology of the parasites of two local species of whiting with respect to season and host age. $\mathrm{BSc}$ honours thesis, Dept Parasitology, University of Queensland, Brisbane

Hedrick RP, Wishkovsky A, Modin JC, Toth RJ (1991) Three myxosporeans found in the cranial and branchial tissues of rainbow trout in California. J Aquat Anim Health 3: $55-62$

Hibiya $T$ (1982) (ed) An atlas of fish histology: normal and pathological features. Gustav Fischer, Tokyo

Kent ML, Whitaker DJ, Margolis L (1993) Transmission of Myxobolus arcticus Pugachev and Khokhlov, 1979, a myxosporean parasite of Pacific salmon, via a triactinomyxon from the aquatic oligochaete Stylodrilus heringianus (Lumbriculidae). Can J Zool 71:1207-1211

Langdon JS (1991) Myoliquefaction post-mortem ('milky flesh') due to Kudoa thyrsites (Gilchrist) (Myxosporea: Multivalvulida) in mahi mahi, Coryphaena hippurus L. $J$ Fish Dis 14:45-54

Lester RJG (1982) Unicapsula seriolae n. sp. (Myxosporea, Multivalvulida) from Australian yellowtail kingfish Seriola lalandi. J Protozool 29:584-587

Lom J, Dyková I (1992) Protozoan parasites of fishes. Elsevier, Amsterdam

Lom J, Rohde K, Dyková I (1992) Studies on protozoan parasites of Australian fishes I. New species of the genera Coccomyxa Leger et Hesse, 1907, Ortholinea Shulman, 1962 and Kudoa Meglitsch, 1947 (Myxozoa, Myxosporea). Folia Parasitol 39:289-306

Maclean JL (1971) The food and feeding of winter whiting (Sillago maculata Quoy and Gaimard) in Moreton Bay. Proc Linn Soc NSW 96:87-92

Responsible Subject Editor: W. Körting, Hannover, Germany
McKay R (1985) A revision of the fishes of the family Sillaginidae. Mem Queensland Mus 22:1-73

Oliva M, Luque JL, Teran L, Llican L (1992) Kudoa scienae (Myxozoa: Multivalvulidae) cysts distribution in the somatic muscles of Stellifer minor (Tschudi, 1844) (Pisces: Sciaenidae). Mem Inst Oswaldo Cruz 87:33-35

Roubal FR (1994) Histopathological and ecological aspects of Henneguya and Myxobolus (Myxosporea) infections in Acanthopagrus australis (Gunther) (Pisces: Sparidae) from Moreton Bay, Australia. J Fish Dis 17:495-512

Roughley TC (1964) Fish and fisheries of Australia. Angus \& Robertson Publ, Sydney

Ruidisch S, El-Matbouli M, Hoffmann RW (1991) The role of tubificid worms as an intermediate host in the life cycle of Myxobolus pavlovskii (Akhmerov, 1954). Parasitol Res 77:663-667

Su XQ. White WG (1994) New myxosporeans (Myxozoa: Myxosporea) from marine fishes of Tasmania, Australia. Acta Protozool 33:251-259

Weng HT (1983) Identification, habitats and seasonal occurrence of juvenile whiting (Sillaginidae) in Moreton Bay, Queensland. J Fish Biol 23:195-200

Whitaker DJ, Kabata Z (1987) Early infection of Merluccius productus (Ayres) (Pisces: Teleostei) with Kudoa thyrsites (Gilchrist) (Myxozoa). Can J Zool 65:936-939

Yokoyama H, Ogawa K, Wakabayashi H (1991) A new collection method of Actinosporeans-a probable infective stage of Myxosporeans to fishes--from tubificids and experimental infection of goldfish with the Actinosporean, Raabeia sp. Gyobyo Kenkyu 26:133-138

Yokoyama H, Ogawa K. Wakabayashi H (1993) Involvement of Branchiura sowerbyi (Oligochaeta: Annelida) in the transmission of Hoferellus carassii (Myxosporea: Myxozoa), the causative agent of kidney enlargement disease (KED) of goldfish Carassius auratus. Gyobyo Kenkyu 28:135-139

Manuscript received: November 11, 1996

Revised version accepted: April 1, 1997 